\title{
Fatty acid composition and regulatory gene expression in late- term embryos of ACRB and COBB broilers
}

\author{
Shengchen Su \\ University of Georgia \\ Yidi Wang \\ University of Manitoba \\ Miyoung Suh \\ University of Manitoba \\ Michael Azain \\ University of Georgia \\ Woo Kyun Kim ( $\nabla$ wkkim@uga.edu ) \\ University of Georgia https://orcid.org/0000-0002-0005-352X
}

\section{Research article}

Keywords: fatty acids, liver, muscle, breed, embryo

Posted Date: November 16th, 2019

DOI: https://doi.org/10.21203/rs.2.17397/v1

License: @ (i) This work is licensed under a Creative Commons Attribution 4.0 International License. Read Full License 


\section{Abstract}

Background:Cobb broilers (COBB) have been heavily selected for their production performance in the past several decades, while the Athens Canadian Random Bred (ACRB) chickens, a meat-type breed, has been kept as a non-selected control strain. The purpose of this study was to compare these two lines of chickens at late-embryonic development and identify the molecular markers and fatty acid profiles underlining their differences in growth performance due to selection. Results: COBB had higher egg weight, embryo weight, and breast and fat ratio. The gene expression in the liver showed an interaction between age and breed on FASN (fatty acid synthase) expression with the highest level in COBB at E18. ACRB had higher Apo-B (apolipoprotein B) and MTTP (microsomal triglyceride transfer protein) expression, but lower SREBP-1(regulatory elementbinding protein 1) expression compared to COBB. No difference was found in myogenesis gene expression in the muscle between two breeds. For the fatty acid composition, muscle was largely affected by both breed and age. Yolk and liver were affected mainly by breed and age, respectively. Constant interaction effects in docosahexaenoic acid (DHA), indicating the highest level in all the tested tissues of ACRB at E14 and the constant main effects with higher myristic, palmitic and gondoic, but lower linolenic acid in the liver and yolk of COBB compared to in those of ACRB. At last, fat accumulation in the liver had no obvious difference between the breeds but was higher when embryo was older. Conclusions: Broiler breed affects egg, embryo and tissue weight, as well as FA composition in initial egg yolk and throughout the embryonic development. The highest docosahexaenoic percentage was observed in ACRB, indicating that genetic selection may result in fatty acid profile changes in chicken tissues and eggs.

\section{Background}

The Athens Canadian Random Bred (ACRB) is an unselected meat-type chicken control stain that originated from the Ottawa meat Control strain (OC) [1]. The OC chicken was developed by the Canada Department of Agriculture's Research Branch using four stains of white plumage birds, which were selected as breeders of ACRB pedigreed eggs in 1955 [2]. Because ACRB was maintained with random breeding, it has not been heavily selected for body weight gain as the commercial broilers, and the genetic of ACRB has been maintained to eliminate commercial selection. It has been used as a control strain in many poultry research to eliminate the environmental effects in breeding programs and to monitor changes in commercial broiler over time [1]. The Cobb 500 chicken (COBB), like other commercial stains, was selected on growth rate, feed efficiency, yield, meat quality, and many other aspects. For example, from 1980 to 2010, weights for the Cobb 500 product at six weeks of age increased from about $1.13 \mathrm{~kg}$ to $2.50 \mathrm{~kg}$ (Cobb-Vantress, 2012).

A few studies have compared ACRB to other commercial broilers during embryonic development. Christensen et al (1995) demonstrated that during late embryonic stage (E18 to E20) ACRB weight was about 70\% of Arbor Acres (AA) embryos [3]. The ACRB also have significant lighter liver and heart weight in this pre-hatch period, but the relative liver and heart weight to body weight is higher in ACRB. Compared to COBB, ACRB embryos required a longer incubation time. The ACRB chicks hatched with a lighter residual yolk sac as a percentage of chick weight. Other parameters such as egg composition, conductance values, and hatch performance were not different between COBB and ACRB [4]. In post-hatch development, other studies showed that COBB had larger breast and leg muscles and had significantly greater fat pad, when compared to ACRB, but had smaller heart and liver as a percentage of body weights [5]. The cross-breed of AA $\times$ Peterson showed higher expression of c-fos and c-mys in the liver from E14 to D28 (post-hatch) of age. Because these two genes are involved in cell proliferation, the result may explain lower organ weight observed in ACRB [6].

Lipogenesis and fatty acid (FA) oxidation are important metabolic pathways in controlling hepatic triacylglycerol content and body fat accumulation $[7,8]$. There are about $30 \%$ lipids in the egg yolk, which are mainly triacylglycerides, phospholipid and cholesterol [9]. In chickens, more than $90 \%$ of the total energy in embryonic development is provided by the yolk lipids [10]. However, as the embryo encounters emergence, it starts to decrease lipid metabolism and rely on tissue glycogen [3] or anaerobic catabolism for energy [11]. Cori cycling and gluconeogenesis were both estimated higher on E19 compared to E14 [12]. 
Many research groups have investigated the expression of hepatic lipid metabolism genes between different broiler breeds after hatch [13-15]. Their results showed that chicken lines with high-fat deposition have higher expression of lipogenesisrelated genes at certain post-hatch development stage. Hepatic gene expression during embryonic development has been less studied. During embryonic development, chicken with high-fat deposition showed higher expression level of fatty acid synthase (FASN) [16] and peroxisome proliferator-activated receptor a (PPARa) [8]. These results suggested that genetic selection has not only modified feed consumption and body composition after hatch but also affected lipogenesis and lipid metabolism within the egg.

In embryonic stages, myoblasts proliferate and differentiate into myotubes, which form the myofibers. Muscle growth during embryonic development is called hyperplasia, which refers to increase of cell number. Muscle growth in post-hatch periods is called hypertrophy, which is increased in size. This is achieved by fusion with satellite cells and increase protein accumulation in myofiber [17]. In mammal, the expression of MYF5 and MYOD regulates myoblast development [18]. In chicken, the expression of MYF5 can be detected in somites at as early as Hamburger-Hamilton stage 9, which is about 29 to 33 hours after incubation initiation [19]. Other molecules in Wnt pathway include PAX3 and PAX7, which have similar yet distinct functions in regulating myoblast differentiation and expression of MYF5 and MYOD [20]. The hedgehog signalling pathway is acknowledged for its function in inhibiting myogenesis [21].

However, few studies have been conducted to understand the roles of breed and embryonic stage on fatty acid profiles and myogenic and lipogenic genes in key organs between selected and unselected chicken breeds during embryonic development. The purpose of this study was to compare the two breeds, ACRB and COBB by examining the embryo growth, gene expression and fatty acid profiling in the tissues of interests between ACRB and COBB during embryonic development.

\section{Results}

\section{Egg, embryo and tissue weight}

Egg weight, embryo weight, embryo: egg weight ratio, and tissue: embryo weight ratio are shown in Table 2. COBB eggs were $14.87 \mathrm{~g}(31 \%)$ and $14.26 \mathrm{~g}(30 \%)$ heavier than ACRB egg on E14 and E18 ( $<<0.0001)$, respectively. COBB embryos were $5.97 \mathrm{~g}$ $(56 \%)$ and $6.91 \mathrm{~g}(31 \%)$ heavier than ACRB on E14 and E18 ( $<<0.0001)$, respectively. Embryo weight relative to egg weight was higher on E18 without breed difference. Relative breast muscle was significantly higher on E14 when compared to E18, and COBB was heavier than ACRB on E14, but no breed difference was observed on E18. Relative liver weight was higher on E18, whereas no breed difference was observed on either day. Relative fat weight was higher on E18 than on E14 (P=0.03), and COBB embryos had higher fat tissue weight than ACRB on E18 $(P=0.0002)$.

\section{Gene expression in the liver and muscle}

Comparison of hepatic lipogenesis and lipid metabolism related gene expression between ACRB and COBB is shown in Figure 1. The main effect of embryonic day was observed in ABCA-1, Apo-B, MTTP, PPAR-a and SREBP; the expression of these genes were significantly higher on E18 when compared to E14. Main effect of breed was shown in Apo-B and MTTP; the gene expression was higher in ACRB than in COBB $(\mathrm{P}<0.05)$. The main effect of breed was also shown in SREBP-1 expression, which was higher in $\mathrm{COBB}(\mathrm{P}, 0.05)$. The only interaction of embryonic age and breed was observed in FASN expression; ACRB on E18 had significantly lower FASN expression compared to ACRB on E14 and COBB on E18.

Comparison of key myogenic genes between ACRB and COBB is shown in Figure 2. The main effect of embryonic day was observed in MEF2c, MYF6, MYOD, MYOG, PAX3, PAX7 and PTCH expression, which indicates higher expression levels of these genes on E14 compared to E18 $(P<0.05)$. No effect of breed or interaction was detected in myogenesis gene expression.

\section{Fatty acid composition analysis}

FA composition (mole \%, w/w) of egg yolk prior to incubation is shown in Table 3. Egg yolk at E0 was abundant in oleic acid followed by palmitic acid. linoleic acid, an essential n- 6 fatty acids, is the dominate among other polyunsaturated fatty acids 
(PUFA). Compared to ACRB at this age, COBB had lower level of oleic acids $(33.63 \%$ vs $42.99 \%, \mathrm{P}<0.001)$ and total monounsaturated FA ( $37.01 \%$ vs. $46.37 \%, P<0.001)$, whereas they had higher essential fatty acids linoleic $(22.36 \%$ vs $15.56 \%$, $P<0.01)$, $y$-linolenic $(0.31 \%$ vs $0.18, P<0.01)$ and a-linolenic acid $(1.18 \%$ vs $0.60 \%, P<0.001)$, leading to higher total $n-6(26.62 \%$ vs $19.18, P<0.01)$ and $n-3$ FA $(2.78 \%$ vs $2.07 \%, P<0.01)$.

FA composition of egg yolk on E14 and E18 is shown in Table 4. While the major FAs are same as E0, the age differences were not identified in all of the FAs analyzed except docosahexaenoic acid (DHA, C22:6n-3, P= 0.027), a major n-3 PUFA showing significant breed and age interaction effect $(\mathrm{P}=0.025)$; ACRB on E14 had significantly higher DHA but lower at E18 compared to COBB on the same age. Arachidonic acid level was decreased with age. Compared to ACRB, COBB had higher myristic-, palmitic-, margaric-, $y$-linolenic (18:3n-6)-, gondoic acids, total saturated fatty acids (SFA), but had lower palmitoleic, linoleic, alinolenic (18:3n-3) and total n-6 FA

In the liver (Table 5), unlike egg yolk, both n-6 and n-3 PUFA became the major fatty acids, especially with arachidonic acid and DHA. In terms of age differences, the most pronounced difference was identified in oleic acid, which was increased 2.4-2.5 times higher in E18 in comparison to E14 in both breeds ( $P<0.0001)$. At E18, both $n-6$ and n-3 essential FAs, linoleic- and alinolenic acids were also significantly $(\mathrm{p}<0.0001)$ increased in both breeds, while decreasing saturated, and arachidonic acid and DHA. In terms of breed difference, compared to ACRB, COBB had significantly higher palmitic-, plamitoleic, godonic and eicosadienoic acids but lower in stearic, a-linolenic acid and DHA.

In the muscle (Table 6), palmitoleic-, stearic, oleic, linoleic, a-linolenic (18:3n-3), gondoic, arachidonic, eicosapentaenoic acids, DHA, total SFA, total mono, and total n-3 FA showed breed and age interaction. Similar to the result of the liver, ACRB on E14 had significantly higher DHA ( $P=0.004)$ and total $n-3 F A(P=0.003)$ compared to the other groups. a-linolenic (18:3n-3), gondoic, eicosadienoic acids, DHA total n-3 FA and total n-6 FA showed breed difference. Myristic, palmitic, linoleic, gondoic and and total n-6 FA showed age difference.

\section{Histology}

Little differences in lipid deposition were observed between the ACRB (Figure 3. A and C) and COBB (Figure 3. B and D) chicken at the same age of embryonic development. However, lipid deposition on E18 was considerably higher than E14 regardless of the breeds.

\section{Discussion}

Egg characteristics and hatch performance of ACRB and COBB were first reported by Collins et, al. in 2014. In their study, egg composition, conductance values, incubation duration, hatch performance, and yolk utilization were measured [4]. The results showed that COBB had higher egg weight and relative albumen, but lower initial yolk weight. Compared to ACRB, COBB also has higher final relative yolk weight, indicating that ACRB chickens utilized more yolk during embryonic development. However, no information on embryo weight or organ/tissue weight was indicated in their comparison of ACRB and COBB broilers. In the current study, from E14 to E18, the relative embryo weight and relative liver weight increased; this result is also supported by Pulikanti et, al (2010) who evaluated the effect of hen age on embryo development from E15 to E19 [22]. In addition, they also observed decrease in relative yolk weight and increase in pipping muscle weight as incubation proceeded. However, no breed difference was observed on either sampling day. In our current study, parameters associated with production, such as egg weight, embryo weight, breast muscle and fat, were high in COBB on at least one time point. These results indicated that selection for growth does affect the embryo development of different breeds of chickens.

The yolk supports the embryonic development of avian species throughout the entire incubation phase. However, rapid absorption of yolk nutrients takes place after the yolk sac has surrounded the yolk on E11 [23, 24]. Lipids from yolk are absorbed by endocytosis of lipoprotein, as no receptors for free FA have been found so far [24]. Some of FAs are synthesized at the yolk sac membrane from other FAs. For example, linoleic acid is converted to arachidonic acid by $\Delta 6$-desaturase [25]. ACRB had higher linoleic acid in the yolk (Figure 4A) and breast muscle (Figure 4E) on E18, but COBB showed higher 
arachidonic acid level in muscle (Figure 4F), despite there is no difference in arachidonic acid level in the yolk (Figure 4B) and muscle (Figure 4D) for the two breeds. This may be because COBB has higher $\Delta 6$-desaturase activity. This result is supported by Cherian and Sim (2001) who found that chicks hatched from eggs enriched with n-3 fatty acid had lower $\Delta 6$-desaturase activity [26].

FA composition differences in the liver were largely affected by embryo age (Table 6). As we observed from the histology results, very little difference was found between the breeds at the same age, whereas there is visible difference between E14 and E18 (Figure 3). Fatty acid composition in the breast muscle showed the most breed and age interaction effects (Table 4). The absolute embryonic breast muscle weight is heavier in COBB when compared to ACRB (data not shown), and at six weeks of age, the weight of breast muscle in COBB is twice of one of ACRB [5]. Hence, as the embryo develops, the COBB breed grows more muscle and deposit more saturated FA and n-6 FA in the muscle. Because high dietary n-6/n-3 ratio may affect obesity [27], these results may explain the heavier fat tissue in COBB chicken in embryonic and post hatch development.

Hepatic triglyceride homeostasis is maintained by regulating FA uptake, de novo lipogenesis, and FA export and/or oxidation [28]. Our results demonstrated that ACRB expressed higher levels of Apo-B and MTTP on E18 when compared to COBB. MTTP plays an important role in synthesis, translocation and secretion of Apo-B-containing lipoproteins in the cell [29]. This result may be partially explained by the fact that ACRB utilizes more yolk than COBB as described above. Some evidence showed that Apo-B also highly expressed in the yolk sac during embryonic development [29]. However, we only investigated the gene expression in the liver in this study. COBB has increased expression of ABCA-1 on E18 compared to ACRB (Figure 2). ABCA-1 interacts with ApoA-1 and controls efflux of cholesterol [30]. Since Apo-B expression in this study was higher in ACRB, detection of ApoA-1 should be included in the future studies to help to understand the expression pattern of ABCA-1 during embryonic development.

ACC and ACLY are both involved in FA/lipid synthesis. ACLY catalyzes the reaction that converts citrate to acetyl-CoA, and ACC carboxylates acetyl-CoA to malonyl-CoA, which is the rate-limiting step in FA synthesis. Both acetyl-CoA and malonyl-CoA are substrates of FASN, the complex they formed gives rise to palmitate as the precursor for many other FAs [31]. ME catalyzes the reaction that generates NADPH, which is used by FASN in synthesizing palmitate [32]. In the current study, higher expression of FASN may indicate that COBB embryos have potentially higher FA synthesis on E18.

In mammals, there are three SREBP isoforms, designated as SREBP-1a, SREBP-1c and SREBP-2. SREBP-2 mainly regulates the synthesis and metabolism of cholesterol, while SREBP-1c preferentially regulates the fatty acid synthesis [33, 34]. The function of SREBP-1c is not as restricted as the other two, which is also involved in adipocytes differentiation and lipogenesis in the cell $[35,36]$.

Chickens only have one SREBP-1 isoform, and it is highly homologous to the SREBP-1a in mammals [12]. In chick embryo hepatocytes, SREBP-1 enhances the expression of ACC by interacting with the nuclear thyroid hormone receptor [37]. In the present study, SREBP-1 showed higher expression in COBB embryos on E14 and E18, which may correspond to the elevated FASN on E18.

In breast muscle, no breed difference was observed, and gene expression was mainly affected by the age of embryo, which is higher expression level at E14 than E18. However, these tested genes have various functions in muscle development. PAX3 and PAX7 promote the proliferation of either satellites cells or C2C12 myoblasts [20]; MYF5 and MYOD1 are associated with myoblast proliferation, and MYOG regulates myoblast differentiation [38]; MYF6 promotes the expression of muscle proteins and other related muscle-specific genes through trans-activation [39]. However, PTCH-1 represses the function of MYOD in myogenesis [21, 40]. We did not expect that genes with opposite function in regulating myogenesis would have the same expression pattern. One of the reasons may be as the embryo developed towards hatching, many of the genes involved in myoblast proliferation and differentiation are downregulated, and muscle growth is shifted to hypertrophy. Furthermore, in E19 chicken, factors promote proliferation, and suppressors for differentiation are presented in the embryo. In contrast, an E10 embryo only has factors promote mitogenesis [41]. These findings may be supporting the results of declined expression of 
many proliferation related gene on E18 when compared to E14. Future studies should examine the expression of genes in protein synthesis and satellite cell specific myogenesis factors.

\section{Conclusions}

In conclusion, broiler breed affects egg, embryo and tissue weight, as well as fatty acid composition in initial egg yolk and throughout the embryonic development. The Cobb chicken was selected for production traits; thus, it has higher egg, embryo, breast muscle and fat weight. Both breed and age affect most of the gene expression changes in liver lipid metabolism. The changes in muscle gene expression are mainly affected by age. In the initial egg yolk, COBB chicken has lower monounsaturated FA but more n-6 and n-3 FA. During development, ACRB has higher n-6 FA in the yolk, compared to COBB. Unlike to yolk, the ACRB liver contains a higher n-3 FA than COBB. An interesting constant interaction effect was found in DHA level that showed the highest level in all the tested tissues of ACRB at E14. More research needs to conduct to define the role of fatty acids in embryo development.

\section{Methods}

\section{Eggs and incubation}

The ACRB breeders were artificially inseminated with pooled semen five days before the incubation. Fertile eggs from the ACRB breeders were collected at the University of Georgia. COBB eggs were collected two days before incubation and obtained from Fieldale Farms hatchery (Lavonia, GA). Eggs were stored at $18.4^{\circ} \mathrm{C}$ and $70 \%$ prior to incubation. 30 eggs from each strain were incubated at $37.5^{\circ} \mathrm{C}$ and $53 \% \mathrm{RH}$. On E7, unfertile eggs were removed from the incubator and each egg was weighted individually.

\section{Sample collection}

Yolk samples of both breeds on E0 were collected for lipid profiling. On E14 and E18, six eggs, which were weighted closest to the average weight in each strain, were collected. Egg weight on the sampling day was recorded, and the embryo was removed for further analyses. Embryos were euthanized by cervical dislocation, followed by washing in PBS three times and dried. Embryo weight was recorded, and breast muscle, liver, and abdominal and thigh adipose tissues were removed and weighed. Liver and breast muscle for gene expression were collected, placed in liquid nitrogen and later stored at $-80{ }^{\circ} \mathrm{C}$. Breast muscle, liver, fat and yolk were sampled for lipid profiling and stored at $-20^{\circ} \mathrm{C}$. Liver specimens collected for histology were fixed in $10 \%$ phosphate buffered formalin (Sigma-Aldrich, St. Louis, MO, USA).

\section{RNA extraction}

Total RNA was extracted from liver tissue using QIAzol Lysis reagent (Qiagen, MD, USA) according to the manufacturer's protocol. RNA quantity and purity were determined using a Nanodrop 1000 spectrophotometer (Thermo Fisher Scientific, Pittsburgh, PA). The cDNA was synthesized from total RNA (2000 ng) using high-capacity cDNA reverse transcription kits (Thermo Fisher Scientific, Waltham, MA) and was diluted to $6.7 \mathrm{ng} / \mathrm{ul}$ for real-time PCR analysis.

\section{Real-time quantitative RT-PCR}

Hepatic lipid metabolism genes, ABCA-1 (ATP-binding cassette 1), ACC (acetyl coenzyme A carboxylase), ACLY (adenosine triphosphate citrate lyase), apoB (apolipoprotein B), FASN (fatty acid synthase), malic enzyme, MTTP (microsomal triglyceride transfer protein), PPARa (peroxisome proliferator-activated receptor a), PPARY (peroxisome proliferator-activated receptor $\mathrm{Y}$ ) and SREBP-1 (sterol regulatory element-binding protein 1) were analyzed by quantitative real time PCR (qRT-PCR). Myogenesis genes, MEF2a (myocyte Enhancer Factor 2A), MEF2c, MYF5 (myogenic factor 5), MYF6, MYOD (myoblast determination protein), MYOG (myogenin), PAX3 (paired box protein Pax-3), PAX7, and PTCH (protein patched homolog) were examined in muscle samples. GAPDH was chosen as the reference gene. The forward and reverse primers for the 12 genes are shown in Table 1. qRT-PCR was performed on an Applied Biosystems StepOnePlus ${ }^{\text {TM }}$ (Thermo Fisher Scientific,Waltham, MA) with iTaq ${ }^{\text {TM }}$ 
Universal SYBR Green Supermix (BioRad, Hercules, CA) using the following conditions for all genes: $95^{\circ} \mathrm{C}$ for 10 min followed by 40 cycles of $95^{\circ} \mathrm{C}$ for $15 \mathrm{~s}$ and $60^{\circ} \mathrm{C}$ for $60 \mathrm{~s}$. Samples were run in duplicate and relative gene expression data were analyzed using the $2-\Delta \Delta \mathrm{Ct}$ method [42]. The mean $\Delta \mathrm{Ct}$ of ACRB at E14 was used to calculate the $\Delta \Delta \mathrm{Ct}$ value.

\section{Fatty acid composition}

To measure fatty acid composition, a direct saponification and methylation method was used for egg yolk, muscle and liver with a slight modification of method developed by Kang and Wang, (2005). In brief, saponification was carried out for all samples by adding $0.5 \mathrm{M}$ methanolic $\mathrm{KOH}$ at $110^{\circ} \mathrm{C}$ for 1 hour, followed by methylation. The separation of fatty acid methyl esters was carried out on a SGE BPX-70 column (10 m X $0.10 \mathrm{~mm}$ diameter and $0.2 \mathrm{~m}$ film thickness), using a Bruker 450 gas chromatography instrument coupled to a flame ionization detector (Bruker, Corporation, CompassXport 3.0, Massachusetts, US). The detailed run conditions have been published elsewhere. [43]

\section{Histology}

Liver tissues collected on E14 and E18 were fixed in 10\% phosphate buffered formalin and were sent to the Poultry Diagnostic and Research Center at the University of Georgia for processing. In brief, samples were embedded in paraffin and cut into sections at $4.0 \mu \mathrm{m}$ thickness and were stained with standard hematoxylin and eosin solution. Slides were examined with an Olympus IX71 inverted research microscope, using bright-filed observation.

\section{Statistical analysis}

Gene expression result, egg, embryo and tissue weights were analyzed by two-way ANOVA using JMP® Statistical Discovery Software from SAS (SAS Institute, Cary, NC). The model contains main effects of breed and embryonic day, and interaction between the two variables. Individual means were further analyzed using Tukey's HSD test $(p<0.05)$. FA profiling data were analyzed by t-test for egg yolk at the baseline and two-way ANOVA for other tissues.

\section{Abbreviations}

ALP- Alkaline Phosphatase Assay; BMP- Bone Morphogenic Protein; BSP- Bone Sialoprotein; BGLAP- Bone Carboxyglutamate Protein; MSCs- Mesenchymal stem cells; cBMSCs- Chicken Compact Bone Derived Mesenchymal Stem Cells; OA- Oleic acid; DMI- Dexamethasone, 3-isobutyl-1-methylxanthine, and Insulin; FBS- Fetal Bovine Serum; DMIOA- Dexamethasone, 3-isobutyl-1methylxanthine, Insulin, and Oleic Acid; qRT-PCR- Quantitative Real-Time Reverse Transcriptase Polymerase Chain Reaction; FABP4- Fatty Acid Binding Protein 4; PPARy2- Peroxisome Proliferator-activated Receptor gamma; DMEM- Dulbecco's Modified Eagle's Medium; SAS- Statistical Analysis System.

\section{Declarations}

\section{Acknowledgements:}

Not applicable

\section{Author's contributions}

WKK and MS bought research ideas and designed the study. SS, YW, and MA conducted the experiment and generated the data. SS and CC wrote the manuscript. All authors read and approved the final version of the manuscript.

\section{Funding}

Not applicable

\section{Availability of data and materials}


All data generated or analyzed during this study are included in this published article. The datasets used and/or analyzed during the current study are available from the corresponding author on reasonable request.

\section{Ethics approval}

All experiments were performed in accordance with the guidelines for the use of animal in research as stated by the Institutional Animal Care and Use Committee at the University of Georgia. The protocol was approved by the Institutional Animal Care and Use Committee at the University of Georgia.

\section{Competing interests}

The authors declare no conflict of interest.

Author information

${ }^{1}$ Department of Poultry Science, University of Georgia, Athens, GA 30602, U.S.A.;

${ }^{2}$ Department of Food and Human Nutritional Sciences, University of Manitoba, Winnipeg, MB, Canada;

${ }^{3}$ Division of Neurodegenerative Disorders \& Canadian Centre for Agri-Food Research in Health and Medicine, St. Boniface Hospital Albrechtsen Research Centre, Winnipeg, MB, Canada;

${ }^{4}$ Department of Animal and Dairy Science, University of Georgia, Athens, GA 30602, U.S.A.

\section{References}

1. Collins KE, Marks HL, Aggrey SE, Lacy MP, Wilson JL: History of the Athens Canadian Random Bred and the Athens Random Bred control populations. Poult Sci 2016, 95(5):997-1004.

2. Hess CW: Randombred Populations of The Southern Regional Poultry Breeding Project. Worlds Poult Sci J 2007, 18(2):147-152.

3. Christensen VL, Havenstein GB, Davis GS: Egg Characteristics, Carbohydrate Metabolism, and Thyroid Hormones in Late Chick Embryos from Different Genetic Lines1. Poult Sci 1995, 74(3):551-562.

4. Collins KE, McLendon BL, Wilson JL: Egg characteristics and hatch performance of Athens Canadian Random Bred 1955 meat-type chickens and 2013 Cobb 500 broilers. Poult Sci 2014, 93(9):2151-2157.

5. Collins KE, Kiepper BH, Ritz CW, McLendon BL, Wilson JL: Growth, livability, feed consumption, and carcass composition of the Athens Canadian Random Bred 1955 meat-type chicken versus the 2012 high-yielding Cobb 500 broiler. Poult Sci 2014, 93(12):2953-2962.

6. Kim JW, Fletcher DL, Campion DR, Gaskins HR, Dean RG: Effect of genetic background on the developmental expression of c-fos and c-myc in chicken. Mol Biol Rep 1992, 16(2):85-90.

7. Jensen-Urstad AP, Semenkovich CF: Fatty acid synthase and liver triglyceride metabolism: housekeeper or messenger? Biochim Biophys Acta 2012, 1821(5):747-753.

8. Zhao S, Ma H, Huang G, Zou S: Hepatic lipolysis in broiler chickens with different fat deposition during embryonic development. Res Vet Sci 2010, 88(2):321-325.

9. Nielsen H: Hen age and fatty acid composition of egg yolk lipid. Br Poult Sci 1998, 39(1):53-56.

10. Noble RC, Cocchi M: Lipid metabolism and the neonatal chicken. Prog Lipid Res 1990, 29(2):107-140.

11. Moran ET, Jr.: Nutrition of the developing embryo and hatchling. Poult Sci 2007, 86(5):1043-1049.

12. Hu Q, Agarwal U, Bequette BJ: Gluconeogenesis, non-essential amino acid synthesis and substrate partitioning in chicken embryos during later development. Poult Sci 2017, 96(2):414-424. 
13. Bourneuf E, Herault F, Chicault C, Carre W, Assaf S, Monnier A, Mottier S, Lagarrigue S, Douaire M, Mosser J et al: Microarray analysis of differential gene expression in the liver of lean and fat chickens. Gene 2006, 372:162-170.

14. Daval S, Lagarrigue S, Douaire M: Messenger RNA levels and transcription rates of hepatic lipogenesis genes in genetically lean and fat chickens. Genet Sel Evol 2000, 32(5):521-531.

15. Cui HX, Zheng MQ, Liu RR, Zhao GP, Chen JL, Wen J: Liver dominant expression of fatty acid synthase (FAS) gene in two chicken breeds during intramuscular-fat development. Mol Biol Rep 2012, 39(4):3479-3484.

16. Zhao S, Ma H, Zou S, Chen W, Zhao R: Hepatic lipogenesis in broiler chickens with different fat deposition during embryonic development. J Vet Med A Physiol Pathol Clin Med 2007, 54(1):1-6.

17. Velleman SG: Muscle development in the embryo and hatchling. Poult Sci 2007, 86(5):1050-1054.

18. Haldar M, Karan G, Tvrdik P, Capecchi MR: Two cell lineages, myf5 and myf5-independent, participate in mouse skeletal myogenesis. Dev Cell 2008, 14(3):437-445.

19. Mok GF, Mohammed RH, Sweetman D: Expression of myogenic regulatory factors in chicken embryos during somite and limb development. J Anat 2015, 227(3):352-360.

20. Collins CA, Gnocchi VF, White RB, Boldrin L, Perez-Ruiz A, Relaix F, Morgan JE, Zammit PS: Integrated functions of Pax3 and Pax7 in the regulation of proliferation, cell size and myogenic differentiation. PLoS One 2009, 4(2):e4475.

21. Gerber AN, Wilson CW, Li YJ, Chuang PT: The hedgehog regulated oncogenes Gli1 and Gli2 block myoblast differentiation by inhibiting MyoD-mediated transcriptional activation. Oncogene 2007, 26(8):1122-1136.

22. Pulikanti SR, Dahidah MS, Agelidis VG: Voltage balancing control of three-level active NPC converter using SHE-PWM. IEEE Trans. Power Del. 2010, 26(1):258-267.

23. Noble R, Cocchi M: Lipid metabolism and the neonatal chicken. Prog Lipid Res 1990, 29(2):107-140.

24. Yadgary L, Wong EA, Uni Z: Temporal transcriptome analysis of the chicken embryo yolk sac. BMC Genom 2014, 15(1):690.

25. Noble RC, Shand JH: Unsaturated fatty acid compositional changes and desaturation during the embryonic development of the chicken (Gallus domesticus). Lipids 1985, 20(5):278-282.

26. Cherian G, Sim J: Maternal dietary a-linolenic acid (18: $3 n-3)$ alters n-3 polyunsaturated fatty acid metabolism and liver enzyme activity in hatched chicks. Poult sci 2001, 80(7):901-905.

27. Simopoulos AP: An Increase in the Omega-6/Omega-3 Fatty Acid Ratio Increases the Risk for Obesity. Nutrients 2016, 8(3):128.

28. Liu Z, Li Q, Liu R, Zhao G, Zhang Y, Zheng M, Cui H, Li P, Cui X, Liu J et al: Expression and methylation of microsomal triglyceride transfer protein and acetyl-CoA carboxylase are associated with fatty liver syndrome in chicken. Poult Sci 2016, 95(6):1387-1395.

29. Eresheim C, Plieschnig J, Ivessa NE, Schneider WJ, Hermann M: Expression of microsomal triglyceride transfer protein in lipoprotein-synthesizing tissues of the developing chicken embryo. Biochimie 2014, 101:67-74.

30. Zhao GJ, Yin K, Fu YC, Tang CK: The interaction of ApoA-I and ABCA1 triggers signal transduction pathways to mediate efflux of cellular lipids. Mol Med 2012, 18:149-158.

31. Ferrier DR: Biochemistry, 6th edn. Philadelphia: Wolters Kluwer Health/Lippincott Williams \& Wilkins; 2014.

32. Hillgartner FB, Salati LM, Goodridge AG: Physiological and molecular mechanisms involved in nutritional regulation of fatty acid synthesis. Physiol Rev 1995, 75(1):47-76.

33. Horton JD, Goldstein JL, Brown MS: SREBPs: activators of the complete program of cholesterol and fatty acid synthesis in the liver. J Clin Invest 2002, 109(9):1125-1131.

34. Hu Y, Sun Q, Li X, Wang M, Cai D, Li X, Zhao R: In Ovo injection of betaine affects hepatic cholesterol metabolism through epigenetic gene regulation in newly hatched chicks. PLOS One 2015, 10(4):e0122643.

35. Kim JB, Spiegelman BM: ADD1/SREBP1 promotes adipocyte differentiation and gene expression linked to fatty acid metabolism. Genes Dev 1996, 10(9):1096-1107. 
36. Moseti D, Regassa A, Kim WK: Molecular Regulation of Adipogenesis and Potential Anti-Adipogenic Bioactive Molecules. Int J Mol Sci 2016, 17(1).

37. Yin L, Zhang Y, Hillgartner FB: Sterol regulatory element-binding protein-1 interacts with the nuclear thyroid hormone receptor to enhance acetyl-CoA carboxylase-alpha transcription in hepatocytes. J Biol Chem 2002, 277(22):19554-19565.

38. te Pas MF, Verburg FJ, Gerritsen CL, de Greef KH: Messenger ribonucleic acid expression of the MyoD gene family in muscle tissue at slaughter in relation to selection for porcine growth rate. J Anim Sci 2000, 78(1):69-77.

39. Fan H, Cinar MU, Phatsara C, Tesfaye D, Tholen E, Looft C, Schellander K: Molecular mechanism underlying the differential MYF6 expression in postnatal skeletal muscle of Duroc and Pietrain breeds. Gene 2011, 486(1-2):8-14.

40. Lewis KE, Currie PD, Roy S, Schauerte H, Haffter P, Ingham PW: Control of muscle cell-type specification in the zebrafish embryo by Hedgehog signalling. Dev Biol 1999, 216(2):469-480.

41. Yablonka-Reuveni Z: Myogenesis in the Chicken: the Onset of Differentiation of Adult Myoblasts is Influenced by Tissue Factors. Basic Appl Myol 1995, 5(1):33-41.

42. Livak KJ, Schmittgen TD: Analysis of relative gene expression data using real-time quantitative PCR and the 2(-Delta Delta C(T)) Method. Methods 2001, 25(4):402-408.

43. Kuny S, Filion M-A, Suh M, Gaillard F, Sauvé Y: Long-term retinal cone survival and delayed alteration of the cone mosaic in a transgenic mouse model of Stargardt-like dystrophy (STGD3). Invest Ophthalmol Vis Sci 2014, 55(1):424-439.

\section{Tables}

Table 1. Primer sequences. 


\begin{tabular}{|c|c|c|c|c|}
\hline Gene $^{1}$ & Forward primer & Reverse primer & Product size & Genome reference \\
\hline ABCA-1 & CCCAACACCAGGGGAATCTC & CAGTTTCCGCAGTTTTGCCA & 135 & NM_204145.2 \\
\hline ACC & TTGTGGCACAGAAGAGGGAA & GTTGGCACATGGAATGGCAG & 161 & NM_205505.1 \\
\hline ACLY & CAAGACGTGGTGCAGGTAAAG & AGAAGGTTCATCTCGGGAGC & 131 & NM_001030540.1 \\
\hline Apo-B & AACATGGCCCAGTATCAGCC & GTGCCGAGCAGTGATACCAT & 137 & NM_001044633.1 \\
\hline FASN & AGAGGCTTTGAAGCTCGGAC & GGTGCCTGAATACTTGGGCT & 127 & NM_205155.2 \\
\hline ME & GCTTGCCAGCATTACGGTTT & TGTCCCCGGTCATGGATAGT & 71 & NM_204303.1 \\
\hline MTTP & CGTCAAGAACCGGATAGCCA & CTGTGAAAACTGCACCGTGG & 133 & NM_001109784.2 \\
\hline PPAR-a & CACTTTTTGTCGCTGCCATCA & GCCGGAGGTCAGCCATTTTT & 177 & NM_001001464.1 \\
\hline PPAR-y & TGAATGTCGTGTGTGTGGGG & GCATTCGCCCAAACCTGATG & 230 & NM_001001460.1 \\
\hline SREBP-1 & TTCTCAGGGCTGTTCGATGC & AACACATTGCCGGTAGGGGG & 119 & NM_204126.2 \\
\hline MEF2a & CTGGCAATGCTGGTGGAATG & АTTCАTССТССТССGTCAGT & 279 & NM_204864.3 \\
\hline MEF2c & TAGGTCACAGCCCTGAGTCT & ATGGGCCAGTGGCAAAAGAT & 203 & XM_004949410.3 \\
\hline MTF5 & GAGGAACGCCATCAGGTACATC & ACATCGGAGCAGCTGGAGCT & 126 & NM_001030363.1 \\
\hline MYF6 & AGGACAAAATGCAGGAGGTG & TCGTCGGAGGAAATGCTGTC & 229 & NM_001030746.1 \\
\hline MYOD & GACAGCAGCTACTACACGGAATCA & GGAAATCCTCTCCACAATGCTT & 102 & NM_204214.2 \\
\hline MYOG & AGCAGCCTCAACCAGCAGGA & TCTGCCTGGTCATCGCTCAG & 179 & NM_204184.1 \\
\hline PAX3 & ACTACCCTGACATTTATACTCG & TGCCTGCTTCCTCCATCTAG & 110 & NM_204269.1 \\
\hline PAX7 & ATGAATCCTGTTAGCAATGGC & GGAGAGATGGAGAAGTCAGC & 101 & NM_205065.1 \\
\hline PTCH & GGCGTTCGCGGTGGGACTAC & GGTGCTGCCGGAGTGCTTCT & 106 & NM_204960.2 \\
\hline GAPDH & GCTAAGGCTGTGGGGAAAGT & TCAGCAGCAGCCTTCACTAC & 161 & NM_204305.1 \\
\hline
\end{tabular}

${ }^{1}$ Abbreviations: ABCA-1 =ATP-binding cassette 1, ACC =acetyl coenzyme A carboxylase, ACLY =adenosine triphosphate citrate lyase, ApoB =apolipoprotein B, FASN =fatty acid synthase, MTTP = Microsomal triglyceride transfer protein, $\mathrm{PPAR} \alpha=$ peroxisome proliferator-activated receptor $\alpha, \mathrm{PPAR} \gamma=$ peroxisome proliferator-activated receptor $\gamma$, and SREBP-1 =sterol regulatory element-binding protein 1, MEF2a=Myocyte Enhancer Factor 2A, MEF2c= Myocyte Enhancer Factor 2C, MYF5 =Myogenic factor 5, MYF6= Myogenic factor 6, MYOD=Myoblast determination protein, MYOG=Myogenin, PAX3=Paired box protein Pax-3, PAX7=Paired box protein Pax-7, PTCH=Protein patched homolog, GAPDH= Glyceraldehyde 3phosphate dehydrogenase.

Table 2. Egg, embryo, and relative embryo and tissue weight on embryonic day 14 and 18. 


\begin{tabular}{llllllll}
\hline & \multicolumn{2}{c}{ E14 } & \multicolumn{2}{c}{ E18 } & \multicolumn{3}{c}{ p-Value } \\
& ACRB & COBB & ACRB & COBB & Breed & Day & Breed*Day \\
\hline Egg WT (g) & $47.77 \pm 0.89^{\mathrm{b}}$ & $62.64 \pm 0.93^{\mathrm{a}}$ & $47.01 \pm 0.84^{\mathrm{b}}$ & $61.27 \pm 0.83^{\mathrm{a}}$ & $<.0001$ & $\mathrm{NS}$ & $\mathrm{NS}$ \\
Embryo WT (g) & $10.72 \pm 0.22^{\mathrm{d}}$ & $16.69 \pm 0.31^{\mathrm{c}}$ & $22.32 \pm 1.32^{\mathrm{b}}$ & $29.23 \pm 1.14^{\mathrm{a}}$ & $<.0001$ & $<.0001$ & $\mathrm{NS}$ \\
\hline$\%$ Embryo $^{1}$ & $22.48 \pm 0.76^{\mathrm{b}}$ & $26.64 \pm 0.33^{\mathrm{b}}$ & $47.48 \pm 2.68^{\mathrm{a}}$ & $47.71 \pm 1.79^{\mathrm{a}}$ & $\mathrm{NS}$ & $<.0001$ & $\mathrm{NS}$ \\
\hline$\%$ Breast $^{2}$ & $2.26 \pm 0.12^{\mathrm{b}}$ & $2.71 \pm 0.11^{\mathrm{a}}$ & $1.04 \pm 0.07^{\mathrm{c}}$ & $1.28 \pm 0.11^{\mathrm{c}}$ & 0.0016 & $<.0001$ & $\mathrm{NS}$ \\
\hline$\%$ Liver $^{2}$ & $1.83 \pm 0.08^{\mathrm{ab}}$ & $1.64 \pm 0.1^{\mathrm{b}}$ & $1.92 \pm 0.11^{\mathrm{ab}}$ & $2.11 \pm 0.17^{\mathrm{a}}$ & $\mathrm{NS}$ & 0.02 & NS \\
\hline$\%$ Fat $^{2}$ & $0.84 \pm 0.08^{\mathrm{b}}$ & $1.08 \pm 0.1^{\mathrm{b}}$ & $0.89 \pm 0.07^{\mathrm{b}}$ & $1.44 \pm 0.13^{\mathrm{a}}$ & 0.0002 & 0.03 & NS \\
\hline
\end{tabular}

${ }^{1}$ Relative embryo weight $(\%)=($ embryo weight/egg weight $) \star 100$.

${ }^{2}$ Relative tissue weight $(\%)=($ tissue weight/embryo weight $) \star 100$.

Values within a row having different superscript letters are statistically different by Tukey's HSD test $(p<0.05)$. ACRB=Athens Canadian Random Bred, NS=not significant.

Table 3. Fatty acid composition of egg yolk from ACRB and Cobb broilers at E0. ${ }^{1}$

\begin{tabular}{|c|c|c|c|c|c|c|c|}
\hline \multicolumn{2}{|c|}{ Fatty Acid (Mol \%) } & \multicolumn{3}{|c|}{$\begin{array}{r}\text { ACRB } \\
(n=6)\end{array}$} & \multicolumn{3}{|c|}{$\begin{array}{l}\text { Cobb } \\
(n=6)\end{array}$} \\
\hline Myristic & $14: 0$ & 0.39 & \pm & 0.02 & 0.42 & \pm & 0.12 \\
\hline Palmitic & 16:0 & 22.73 & \pm & 2.37 & 23.76 & \pm & 1.00 \\
\hline Palmitoleic & $16: 1 n-7$ & 2.93 & \pm & 0.26 & 2.85 & \pm & 0.49 \\
\hline Margaric & $17: 0$ & 0.11 & \pm & 0.06 & 0.20 & \pm & 0.11 \\
\hline Stearic & $18: 0$ & 9.10 & \pm & 0.85 & 9.01 & \pm & 0.38 \\
\hline Oleic & $18: 1 n-9$ & 42.99 & \pm & 2.62 & 33.63 & \pm & $1.48 * \star \star$ \\
\hline Linoleic & $18: 2 n-6$ & 15.56 & \pm & 1.93 & 22.36 & \pm & $2.58^{\star \star}$ \\
\hline$\gamma$-Linolenic & $18: 3 n-6$ & 0.18 & \pm & 0.05 & 0.31 & \pm & $0.03^{\star \star}$ \\
\hline a-Linolenic & $18: 3 n-3$ & 0.60 & \pm & 0.08 & 1.18 & \pm & 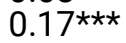 \\
\hline Arachidic & $20: 0$ & 0.01 & \pm & 0.00 & 0.02 & \pm & 0.03 \\
\hline Gondoic & $20: 1 n-9$ & 0.29 & \pm & 0.03 & 0.32 & \pm & 0.01 \\
\hline Eicosadienoic & $20: 2 n-6$ & 0.01 & \pm & 0.00 & 0.01 & \pm & 0.01 \\
\hline Dihomo-y-linolenic & $20: 3 n-6$ & 0.14 & \pm & 0.01 & 0.27 & \pm & $0.02^{\star \star \star}$ \\
\hline Arachidonic & $20: 4 n-6$ & 2.21 & \pm & 0.12 & 2.45 & \pm & 0.30 \\
\hline Eicosapentaenoic & $20: 5 n-3$ & 0.03 & \pm & 0.00 & 0.04 & \pm & 0.01 * \\
\hline Docosahexaenoic & $22: 6 n-3$ & 1.25 & \pm & 0.12 & 1.25 & \pm & \\
\hline Total SFA & & $32.38 \pm$ & & 2.48 & 33.58 & \pm & 1.18 \\
\hline Total Mono & & 46.37 & \pm & 2.75 & 37.01 & \pm & $1.91^{\star \star \star \star}$ \\
\hline Total n-6 FA & & 19.18 & \pm & 1.89 & 26.62 & \pm & $2.72^{\star \star \star}$ \\
\hline Total n-3 FA & & 2.07 & \pm & 0.17 & 2.78 & \pm & $0.26^{\star \star}$ \\
\hline
\end{tabular}

${ }^{1}$ Values are Mean \pm SD. Significant differences between the strains were identified by t-test; $*=p<0.05, * \star=p<0.01, \star \star \star=p<0.001$. ACRB=Athens Canadian Random, SFA=saturated fatty acid, Mono=monounsaturated fatty acids.

Table 4. Fatty acid composition of the yolk from ACRB and Cobb broiler embryos at E14 and E18. ${ }^{1}$ 


\begin{tabular}{|c|c|c|c|c|c|c|c|c|c|c|c|c|}
\hline \multirow{2}{*}{\multicolumn{2}{|c|}{ Fatty Acid (Mol \%) }} & \multicolumn{4}{|c|}{ E14 } & \multicolumn{3}{|c|}{ E18 } & \multicolumn{4}{|c|}{$\mathrm{P}$ value } \\
\hline & & & $\begin{array}{l}\text { ACRB } \\
(n=6)\end{array}$ & & $\begin{array}{l}\text { Cobb } \\
n=6)\end{array}$ & $\begin{array}{l}A C \\
(n=\end{array}$ & & $\begin{array}{c}\text { Cobb } \\
(n=6)\end{array}$ & & eed & Bre & $d^{\star}$ Age \\
\hline ristic & $14: 0$ & $0.30_{+}$ & $0.01^{b}$ & 0.45 & $0.02^{\mathrm{a}}$ & $0.34_{+}$ & $0.02^{b}$ & $0.45_{+}$ & $0.01^{a}$ & $<0.0001$ & NS & NS \\
\hline mitic & $16: 0$ & $24.22^{\underline{1}}$ & $0.42^{\mathrm{b}}$ & $26.71^{1}$ & $0.52^{\mathrm{a}}$ & $24.87^{+}$ & $0.48^{\mathrm{b}}$ & $26.66^{\underline{1}}$ & $0.54^{a}$ & 0.0001 & NS & NS \\
\hline mitoleic & $\begin{array}{l}16: 1 n- \\
7\end{array}$ & $\begin{array}{r}2.99^{-} \\
+\end{array}$ & $0.18^{b}$ & $3.91_{+}^{-}$ & $0.34^{\mathrm{ab}}$ & $3.13^{-}$ & $0.23^{\mathrm{ab}}$ & ${ }^{3.95}$ & $0.30^{\mathrm{a}}$ & 0.002 & NS & NS \\
\hline rgaric & $17: 0$ & $0.18^{-1}$ & 0.01 & $0.19^{-}$ & 0.01 & $0.18^{-1}$ & 0.01 & $0.24^{-}$ & 0.03 & 0.04 & NS & NS \\
\hline aric & $18: 0$ & $8.55^{ \pm}$ & 0.35 & $9.11^{ \pm}$ & 0.22 & $8.16^{ \pm}$ & 0.40 & $8.80^{ \pm}$ & 0.28 & NS & NS & NS \\
\hline ic & $\begin{array}{l}18: 1 n- \\
9\end{array}$ & $40.27^{ \pm}$ & 1.31 & $39.10^{ \pm}$ & 0.86 & $40.52^{ \pm}$ & 1.13 & $38.89^{ \pm}$ & 0.39 & NS & NS & NS \\
\hline oleic & $18: 2 n-$ & $17.17^{-}$ & $1.43^{\mathrm{ab}}$ & $14.40^{-}$ & $0.34^{b}$ & $17.67^{+}$ & $0.77^{a}$ & $14.30_{+}^{+}$ & $0.52^{\mathrm{b}}$ & 0.001 & NS & NS \\
\hline inolenic & $\begin{array}{l}18: 3 n- \\
6\end{array}$ & $\begin{array}{r}0.04^{-} \\
\pm\end{array}$ & 0.01 & $\begin{array}{r}0.06^{-} \\
\pm\end{array}$ & 0.01 & $\begin{array}{r}0.04^{-} \\
\pm\end{array}$ & 0.00 & $\begin{array}{r}0.06^{\frac{1}{-}} \\
\pm\end{array}$ & 0.01 & 0.01 & NS & NS \\
\hline inolenic & $\begin{array}{l}18: 3 n- \\
3\end{array}$ & $0.64_{ \pm}$ & $0.09^{a}$ & ${ }_{ \pm}^{0.38^{-}}$ & $0.02^{b}$ & $0.67_{ \pm}$ & $0.04^{a}$ & $0.37_{ \pm}$ & $0.02^{b}$ & $<0.0001$ & NS & NS \\
\hline chidic & $20: 0$ & ${ }_{ \pm}^{0.03}$ & 0.00 & $\begin{array}{r}0.04 \\
\pm\end{array}$ & 0.00 & $0.04^{-}$ & 0.01 & $0.03^{-}$ & 0.00 & NS & NS & NS \\
\hline רdoic & $\begin{array}{l}20: 1 n- \\
9\end{array}$ & ${ }_{ \pm}^{0.22}$ & $0.02^{\mathrm{c}}$ & $\begin{array}{r}0.29^{-} \\
\pm\end{array}$ & $0.01^{\mathrm{ab}}$ & ${ }_{ \pm}^{0.23^{-}}$ & $0.03^{b c}$ & $\begin{array}{r}0.30^{-} \\
\pm\end{array}$ & $0.01^{\mathrm{a}}$ & 0.0003 & NS & NS \\
\hline osadienoic & $\begin{array}{l}20: 2 n- \\
6\end{array}$ & 0.17 & 0.03 & $0.17_{ \pm}$ & 0.01 & ${ }_{ \pm}^{0.16^{-}}$ & 0.03 & $0.18 \pm$ & 0.02 & NS & NS & NS \\
\hline chidonic & $\begin{array}{l}20: 4 n- \\
6\end{array}$ & $\begin{array}{c}2.16^{-} \\
\pm\end{array}$ & 0.11 & $\begin{array}{r}2.16^{-} \\
\pm\end{array}$ & 0.09 & $\begin{array}{r}1.89^{-} \\
\pm\end{array}$ & 0.16 & $\begin{array}{r}1.95 \\
\pm\end{array}$ & 0.10 & NS & 0.04 & NS \\
\hline osapentaenoic & $\begin{array}{l}20: 5 n- \\
3\end{array}$ & $\begin{array}{r}0.87 \\
\pm\end{array}$ & 0.14 & $\begin{array}{r}0.59 \\
\pm\end{array}$ & 0.12 & $\begin{array}{r}0.54 \\
\pm\end{array}$ & 0.20 & ${ }_{ \pm}^{1.51}$ & 0.68 & NS & NS & NS \\
\hline zosahexaenoic & $\begin{array}{l}22: 6 n- \\
3\end{array}$ & $\begin{array}{r}0.81 \\
\pm\end{array}$ & $0.06^{\mathrm{a}}$ & ${ }_{ \pm}^{0.41}$ & $0.03^{b}$ & $\begin{array}{r}0.37 \\
\pm\end{array}$ & $0.07^{b c}$ & ${ }_{ \pm}^{0.20}$ & $0.03^{c}$ & $<0.0001$ & $<0.0001$ & 0.027 \\
\hline al SFA & & $\begin{array}{r}33.28 \\
\pm\end{array}$ & $0.67^{b}$ & 36.49 & $0.40^{\mathrm{a}}$ & $\begin{array}{c}33.60 \\
\pm\end{array}$ & $0.70^{b}$ & $\begin{array}{c}36.17 \\
\pm\end{array}$ & $0.57^{a}$ & $<0.0001$ & NS & NS \\
\hline al Mono & & $43.67_{ \pm}^{-}$ & 1.38 & ${ }_{ \pm}^{43.56^{-}}$ & 0.61 & $\begin{array}{c}44.08 \\
\pm\end{array}$ & 1.33 & $43.47 \pm$ & 0.49 & NS & NS & NS \\
\hline al n-6 FA & & $\begin{array}{l}19.54^{-} \\
\pm\end{array}$ & $1.42^{\mathrm{ab}}$ & ${ }_{ \pm}^{16.80^{-}}$ & $0.33^{\mathrm{ab}}$ & $\begin{array}{c}19 . \overline{7} 5_{ \pm} \\
\end{array}$ & $0.84^{\mathrm{a}}$ & $\begin{array}{r}16.49^{-} \\
\end{array}$ & $0.51^{\mathrm{b}}$ & 0.001 & NS & NS \\
\hline al n-3 FA & & $\begin{array}{r}2.31 \\
\pm\end{array}$ & 0.16 & $\begin{array}{r}1.38^{-} \\
\pm\end{array}$ & 1.03 & $\begin{array}{r}1.57^{-} \\
\pm\end{array}$ & 0.21 & $\begin{array}{r}2.08^{-} \\
\pm\end{array}$ & 0.67 & NS & NS & 0.05 \\
\hline
\end{tabular}

${ }^{1}$ Values are mean \pm SD. Significant effects were identified by two-way analysis of variance procedures for breed and age. Values within a raw having a different superscript letters are different $(p<0.05)$. ACRB, Athens Canadian Random Bred meattype chicken; SFA, saturated fatty acid; Mono monounsaturated fatty acids; FA, fatty acids; NS, not significant.

Table 5. Fatty acid composition of the liver from ACRB and Cobb broiler embryos at E14 and E18. ${ }^{1}$ 


\begin{tabular}{|c|c|c|c|c|c|c|c|c|c|c|c|c|}
\hline \multirow{2}{*}{\multicolumn{2}{|c|}{ Fatty Acid (Mol \%) }} & \multicolumn{4}{|c|}{ E14 } & \multicolumn{3}{|c|}{ E18 } & \multicolumn{4}{|c|}{$\mathrm{P}$ value } \\
\hline & & \multicolumn{2}{|c|}{$\begin{array}{l}\text { ACRB } \\
(n=6)\end{array}$} & \multicolumn{2}{|l|}{$\begin{array}{l}\text { Cobb } \\
(n=6)\end{array}$} & $\begin{array}{l}\text { ACRB } \\
(n=6)\end{array}$ & \multirow{2}{*}{$0.04^{\mathrm{C}}$} & \multirow{2}{*}{$\begin{array}{r}\begin{array}{c}\text { Cobb } \\
(\mathrm{n}=6)\end{array} \\
0.23 \\
\pm\end{array}$} & \multicolumn{2}{|c|}{ Breed } & \multicolumn{2}{|c|}{ Breed*Age } \\
\hline ristic & $14: 0$ & $0.14_{+}$ & $0.06^{\mathrm{bc}}$ & $0.19_{+}$ & $0.05^{\mathrm{ab}}$ & $0.08_{+}$ & & & $0.08^{a}$ & 0.001 & NS & NS \\
\hline mitic & $16: 0$ & $16.75^{-}$ & $1.31^{b}$ & $18.40^{-}$ & $0.66^{a}$ & $9.93^{-}$ & $1.64^{c}$ & $\begin{array}{l}10.85^{-} \\
+\end{array}$ & $0.83^{c}$ & 0.01 & $<0.0001$ & NS \\
\hline mitoleic & $16: 1 n-$ & $0.14+$ & $0.04^{c}$ & $0.37_{+}^{+}$ & $0.13^{b}$ & $0.36^{+}$ & $0.08^{\mathrm{b}}$ & $1.44^{+}$ & $0.22^{\mathrm{a}}$ & $<0.0001$ & $<0.0001$ & $<0.0001$ \\
\hline rgaric & $17: 0$ & $0.19^{-}$ & 0.21 & $0.18^{+}$ & 0.17 & $0.27^{-1}$ & 0.12 & $0.11^{1}$ & 0.12 & NS & NS & NS \\
\hline aric & $18: 0$ & $17.73^{-}$ & $1.08^{a}$ & $16.30^{+}$ & $0.76^{b}$ & $11.48^{+}$ & $1.76^{\mathrm{c}}$ & $10.72^{-}$ & $0.79^{c}$ & 0.03 & $<0.0001$ & NS \\
\hline ic & $\begin{array}{l}18: 1 \\
n-9\end{array}$ & $\begin{array}{r}18.66^{\underline{1}} \\
\pm\end{array}$ & $3.09^{b}$ & ${ }_{ \pm}^{18.07^{\underline{-}}}$ & $1.27^{b}$ & $\begin{array}{r}43.99^{-} \\
\pm\end{array}$ & $5.93^{a}$ & $\begin{array}{r}45.73^{1} \\
\pm\end{array}$ & $3.38^{a}$ & NS & $<0.0001$ & NS \\
\hline oleic & $\begin{array}{l}18: 2 n- \\
6\end{array}$ & $\begin{array}{r}9.20 \\
\pm\end{array}$ & $1.71^{b}$ & $\begin{array}{r}9.51 \\
\pm\end{array}$ & $1.21^{\mathrm{b}}$ & $\begin{array}{r}13.25^{-} \\
\pm\end{array}$ & $1.85^{\mathrm{a}}$ & $\begin{array}{r}12.01^{-} \\
\pm\end{array}$ & $0.61^{a}$ & NS & $<0.0001$ & NS \\
\hline inolenic & $\begin{array}{l}18: 3 n- \\
6\end{array}$ & & $0.02^{b}$ & $\begin{array}{r}0.04 \\
\pm\end{array}$ & $0.02^{\mathrm{ab}}$ & $\begin{array}{r}0.05^{-} \\
\pm\end{array}$ & $0.03^{\mathrm{ab}}$ & $\begin{array}{r}0.08^{-} \\
\pm\end{array}$ & $0.05^{a}$ & NS & 0.05 & NS \\
\hline inolenic & $\begin{array}{l}18: 3 n- \\
3\end{array}$ & $\begin{array}{r}0.14 \\
\pm\end{array}$ & $0.06^{c}$ & $\begin{array}{c}0.06 \\
\pm\end{array}$ & $0.03^{d}$ & ${ }_{ \pm}^{0.29}$ & $0.06^{a}$ & ${ }_{ \pm}^{0.22}$ & $0.04^{\mathrm{b}}$ & 0.001 & $<0.0001$ & NS \\
\hline chidic & $20: 0$ & $\begin{array}{r}0.09 \\
\pm\end{array}$ & $0.10^{\mathrm{ab}}$ & $\begin{array}{r}0.15 \\
\pm\end{array}$ & $0.05^{\mathrm{a}}$ & $\begin{array}{r}0.04 \\
\pm\end{array}$ & $0.03^{b}$ & $\begin{array}{r}0.04 \\
\pm\end{array}$ & $0.03^{b}$ & NS & 0.005 & NS \\
\hline רdoic & $\begin{array}{l}20: 1 n- \\
9\end{array}$ & $\begin{array}{r}0.23 \\
\pm\end{array}$ & $0.05^{b}$ & $\begin{array}{r}0.32 \\
\pm\end{array}$ & $0.02^{\mathrm{a}}$ & $\begin{array}{r}0.21^{-} \\
\pm\end{array}$ & $0.03^{b}$ & $\begin{array}{r}0.33^{-} \\
\pm\end{array}$ & $0.04^{\mathrm{a}}$ & $<0.0001$ & NS & NS \\
\hline ssadienoic & $\begin{array}{l}20: 2 n- \\
6\end{array}$ & $\begin{array}{r}0.01 \\
\pm\end{array}$ & $0.01^{b}$ & $\begin{array}{r}0.03 \\
\pm\end{array}$ & $0.01^{b}$ & ${ }_{ \pm}^{0.03}$ & $0.03^{b}$ & ${ }_{ \pm}^{0.07}$ & $0.01^{\mathrm{a}}$ & 0.003 & 0.01 & NS \\
\hline chidonic & $\begin{array}{l}20: 4 n- \\
6\end{array}$ & $\begin{array}{r}20.22 \\
\pm\end{array}$ & $1.00^{\mathrm{a}}$ & $\begin{array}{r}20.17 \\
\pm\end{array}$ & $1.11^{\mathrm{a}}$ & $\begin{array}{r}10.66 \\
\pm\end{array}$ & $1.38^{b}$ & $\begin{array}{r}9.55 \\
\pm\end{array}$ & $1.12^{\mathrm{b}}$ & NS & $<0.0001$ & NS \\
\hline osapentaenoic & $\begin{array}{l}20: 5 n- \\
3\end{array}$ & $\begin{array}{r}0.17 \pm \\
\pm\end{array}$ & 0.09 & $0.12 \pm$ & 0.07 & $\begin{array}{r}0.13^{-} \\
\pm\end{array}$ & 0.03 & $\begin{array}{r}0.12 \\
\pm\end{array}$ & 0.01 & NS & NS & NS \\
\hline zosahexaenoic & $\begin{array}{l}22: 6 n- \\
3\end{array}$ & $\begin{array}{r}11.47 \\
\pm\end{array}$ & $1.21^{\mathrm{a}}$ & $\begin{array}{r}7.42 \\
\pm\end{array}$ & $1.06^{\mathrm{b}}$ & $\begin{array}{r}6.14 \\
\pm\end{array}$ & $0.66^{c}$ & $\begin{array}{r}4.00 \\
\pm\end{array}$ & $0.77^{d}$ & $<0.0001$ & $<0.0001$ & 0.025 \\
\hline al SFA & & $\begin{array}{r}35.32 \\
\pm\end{array}$ & $2.22^{\mathrm{a}}$ & $\begin{array}{r}35.77 \\
\pm\end{array}$ & $1.17^{a}$ & $22.02 \pm$ & $3.01^{b}$ & $\begin{array}{r}22.18 \\
\pm\end{array}$ & $1.44^{\mathrm{b}}$ & NS & $<0.0001$ & NS \\
\hline al Mono & & $\begin{array}{c}19.75^{-} \\
\pm\end{array}$ & $3.10^{\mathrm{b}}$ & $19.15^{ \pm}$ & $1.32^{\mathrm{b}}$ & $45.07^{-}$ & $5.94^{\mathrm{a}}$ & $47.83^{ \pm}$ & $3.47^{a}$ & NS & $<0.0001$ & NS \\
\hline al n-6 FA & & $32.61_{ \pm}^{ \pm}$ & $1.42^{\mathrm{b}}$ & $36.70^{-}$ & $1.59^{a}$ & $25.95^{-}$ & $2.86^{c}$ & $25.31_{ \pm}^{-}$ & $1.61^{\mathrm{c}}$ & 0.05 & $<0.0001$ & 0.008 \\
\hline al n-3 FA & & $\begin{array}{r}12.32 \\
\pm\end{array}$ & $1.21^{\mathrm{a}}$ & $\begin{array}{r}8.38^{-} \\
\pm\end{array}$ & $1.08^{b}$ & $\begin{array}{r}6.95^{-} \\
\pm\end{array}$ & $0.68^{c}$ & $\begin{array}{r}4.69 \\
\pm \\
\end{array}$ & $0.81^{d}$ & $<0.0001$ & $<0.0001$ & 0.05 \\
\hline
\end{tabular}

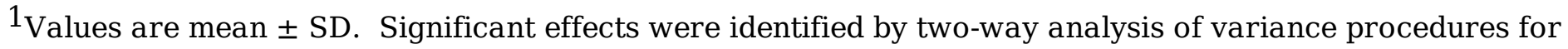
breed and age. Values within a raw having a different superscript letters are different ( $\mathrm{p}<0.05)$. ACRB, Athens Canadian Random Bred meat-type chicken; SFA, saturated fatty acid; Mono monounsaturated fatty acids; FA, fatty acids; NS, not significant.

Table 6. Fatty acid composition of the muscle from ACRB and Cobb broiler embryos at E14 and E18. ${ }^{1}$ 


\begin{tabular}{|c|c|c|c|c|c|c|c|c|c|c|c|c|}
\hline \multirow{2}{*}{\multicolumn{2}{|c|}{ Fatty Acid (Mol \%) }} & \multicolumn{4}{|c|}{ E14 } & \multicolumn{4}{|c|}{ E18 } & \multicolumn{3}{|c|}{$P$ value } \\
\hline & & & $\begin{array}{l}\text { ACRB } \\
(n=6)\end{array}$ & $\begin{array}{l}\mathrm{Co} \\
(\mathrm{n}=\end{array}$ & $\begin{array}{l}\text { bb } \\
=6)\end{array}$ & $\begin{array}{l}\text { ACRB } \\
(n=5)\end{array}$ & & $\begin{array}{l}\text { Cobb } \\
(\mathrm{n}=6)\end{array}$ & & Breed & & Breed*Age \\
\hline ristic & $14: 0$ & $\begin{array}{r}0.49 \\
\pm\end{array}$ & $0.11^{\mathrm{a}}$ & $0.51_{ \pm}$ & $0.16^{a}$ & $\begin{array}{r}0.45 \\
\pm\end{array}$ & $0.18^{a}$ & $0.23_{ \pm}$ & $0.12^{b}$ & NS & 0.02 & NS \\
\hline mitic & $16: 0$ & 24.22 & $0.29^{a b}$ & $25.54_{+}^{-}$ & $1.03^{a}$ & $23.45^{+}$ & $1.66^{b}$ & $23.38^{-}$ & $1.00^{\mathrm{b}}$ & NS & 0.005 & NS \\
\hline mitoleic & $\begin{array}{l}16: 1 n- \\
7\end{array}$ & $0.39^{ \pm}$ & $0.11^{\mathrm{ab}}$ & $0.83^{ \pm}$ & $0.46^{a}$ & $0.67^{ \pm}$ & $0.48^{\mathrm{ab}}$ & $0.35^{ \pm}$ & $0.21^{b}$ & NS & NS & 0.02 \\
\hline rgaric & $17: 0$ & $0.03_{+}^{-}$ & 0.02 & $0.18^{-}$ & 0.24 & $0.17^{-}$ & 0.25 & $0.02^{-}$ & 0.01 & NS & NS & NS \\
\hline aric & 18:0 & $15.58^{\mathrm{I}}$ & $0.68^{a b}$ & $13.43^{\mathrm{I}}$ & $2.07^{b}$ & $13.92^{\mathrm{I}}$ & $2.15^{b}$ & $16.91_{ \pm}^{I}$ & $1.42^{\mathrm{a}}$ & NS & NS & 0.002 \\
\hline ic & $\begin{array}{l}18: 1 n- \\
9\end{array}$ & $\begin{array}{r}20.85 \\
\pm\end{array}$ & $1.62^{b}$ & $\begin{array}{r}23.22 \\
\pm\end{array}$ & $4.66^{\mathrm{ab}}$ & $\begin{array}{r}25.99 \\
\pm\end{array}$ & $3.59^{a}$ & $\begin{array}{r}20.05 \\
\pm\end{array}$ & $3.34^{b}$ & NS & NS & 0.01 \\
\hline oleic & $\begin{array}{l}18: 2 n- \\
6\end{array}$ & $\begin{array}{r}8.91^{-} \\
\pm\end{array}$ & $1.86^{\mathrm{b}}$ & $\begin{array}{c}9.55^{-} \\
\pm\end{array}$ & $2.34^{\mathrm{b}}$ & ${ }_{ \pm}^{15.22}$ & $3.42^{\mathrm{a}}$ & $\begin{array}{r}10.45^{t} \\
\end{array}$ & $0.88^{b}$ & NS & 0.002 & 0.01 \\
\hline inolenic & $\begin{array}{l}18: 3 n- \\
6\end{array}$ & $\begin{array}{r}0.09^{-} \\
\pm\end{array}$ & 0.07 & $\begin{array}{r}0.11^{-} \\
\end{array}$ & 0.07 & $\begin{array}{r}0.09^{-} \\
\pm\end{array}$ & 0.06 & $\begin{array}{r}0.03^{-} \\
\pm\end{array}$ & 0.01 & NS & NS & NS \\
\hline inolenic & $\begin{array}{l}18: 3 n- \\
3\end{array}$ & ${ }_{ \pm}^{0.13^{-}}$ & $0.18^{b}$ & $\begin{array}{r}0.19^{-} \\
\pm\end{array}$ & $0.18^{b}$ & $\begin{array}{r}0.51^{-} \\
\end{array}$ & $0.26^{a}$ & $0.03_{ \pm}^{-}$ & $0.02^{b}$ & 0.02 & NS & 0.003 \\
\hline chidic & $20: 0$ & $\begin{array}{r}0.38^{-} \\
\pm\end{array}$ & 0.16 & 0.24 & 0.21 & $0.17_{ \pm}^{-}$ & 0.29 & $\begin{array}{r}0.39^{-} \\
\pm\end{array}$ & 0.03 & NS & NS & NS \\
\hline רdoic & $\begin{array}{l}20: 1 n- \\
9\end{array}$ & $\begin{array}{r}0.38 \\
\pm\end{array}$ & $0.03^{b}$ & $\begin{array}{r}0.44 \\
\pm\end{array}$ & $0.02^{\mathrm{a}}$ & $\begin{array}{r}0.29 \\
\pm\end{array}$ & $0.04^{c}$ & $\begin{array}{r}0.40 \\
\pm\end{array}$ & $0.02^{\mathrm{ab}}$ & $<0.0001$ & $<0.0001$ & 0.03 \\
\hline osadienoic & $\begin{array}{l}20: 2 n- \\
6\end{array}$ & $\begin{array}{r}0.02 \\
\pm\end{array}$ & $0.01^{\mathrm{ab}}$ & ${ }_{ \pm}^{0.03}$ & $0.01^{a}$ & $\begin{array}{r}0.01 \\
\pm\end{array}$ & $0.02^{b}$ & ${ }_{ \pm}^{0.03}$ & $0.01^{\mathrm{a}}$ & 0.02 & NS & NS \\
\hline chidonic & $\begin{array}{l}20: 4 n- \\
6\end{array}$ & ${ }_{ \pm}^{12.42}$ & $0.97^{a}$ & $\begin{array}{r}11.20 \\
\pm\end{array}$ & $2.90^{\mathrm{ab}}$ & $\begin{array}{r}8.59 \\
\pm\end{array}$ & $3.10^{b}$ & $\begin{array}{r}12.67 \\
\pm\end{array}$ & $1.56^{\mathrm{a}}$ & NS & NS & 0.01 \\
\hline osapentaenoic & $\begin{array}{l}20: 5 n- \\
3\end{array}$ & ${ }_{ \pm}^{0.32}$ & $0.03^{a}$ & $\begin{array}{r}0.22 \\
\pm\end{array}$ & $0.07^{b}$ & ${ }_{ \pm}^{0.22}$ & $0.09^{b}$ & ${ }_{ \pm}^{0.28}$ & $0.05^{\mathrm{ab}}$ & NS & NS & 0.01 \\
\hline zosahexaenoic & $\begin{array}{l}22: 6 n- \\
3\end{array}$ & $\begin{array}{r}8.76 \\
\pm\end{array}$ & $0.83^{a}$ & $\begin{array}{r}5.45 \\
\pm\end{array}$ & $1.29^{b}$ & $\begin{array}{r}5.25 \\
\pm\end{array}$ & $1.60^{b}$ & $\begin{array}{r}5.19 \\
\pm\end{array}$ & $0.72^{b}$ & 0.003 & 0.001 & 0.004 \\
\hline al SFA & & $\begin{array}{r}41.90 \\
\pm\end{array}$ & $1.27^{a}$ & $\begin{array}{r}40.88 \\
\pm\end{array}$ & $1.57^{a}$ & $\begin{array}{r}38.90_{ \pm} \\
\end{array}$ & $2.10^{b}$ & $\begin{array}{r}41.80_{ \pm} \\
\end{array}$ & $0.53^{a}$ & NS & NS & 0.006 \\
\hline al Mono & & $\begin{array}{r}22.75^{-} \\
\pm\end{array}$ & $1.84^{b}$ & $\begin{array}{r}25.22^{ \pm} \\
\pm\end{array}$ & $4.88^{\mathrm{ab}}$ & $\begin{array}{r}27.60^{-} \\
\pm\end{array}$ & $3.85^{a}$ & $\begin{array}{r}21.55^{-} \\
\pm\end{array}$ & $3.46^{b}$ & NS & NS & 0.01 \\
\hline al n-6 FA & & $\begin{array}{r}25.37 \\
\pm\end{array}$ & $1.80^{\mathrm{b}}$ & $\begin{array}{r}27.36 \\
\pm\end{array}$ & $2.30^{b}$ & $\begin{array}{r}26.92 \\
\pm\end{array}$ & $1.62^{b}$ & $\begin{array}{r}30.13 \\
\pm\end{array}$ & $2.51^{\mathrm{a}}$ & 0.007 & 0.02 & NS \\
\hline al n-3 FA & & $\begin{array}{r}9.98 \\
\pm\end{array}$ & $0.87^{a}$ & $\begin{array}{r}6.55 \\
\pm \\
\end{array}$ & $1.29^{b}$ & $\begin{array}{r}6.57 \\
\pm \\
\end{array}$ & $1.58^{\mathrm{b}}$ & $\begin{array}{r}6.52 \\
\pm \\
\end{array}$ & $0.70^{b}$ & 0.002 & 0.003 & 0.003 \\
\hline
\end{tabular}

${ }^{1}$ Values are mean \pm SD. Significant effects were identified by two-way analysis of variance procedures for breed and age. Values within a raw having different superscript letters are different $(p<0.05)$. ACRB, Athens Canadian Random Bred meat-type chicken; SFA, saturated fatty acid; Mono monounsaturated fatty acids; FA, fatty acids; NS, not significant.

Figures 


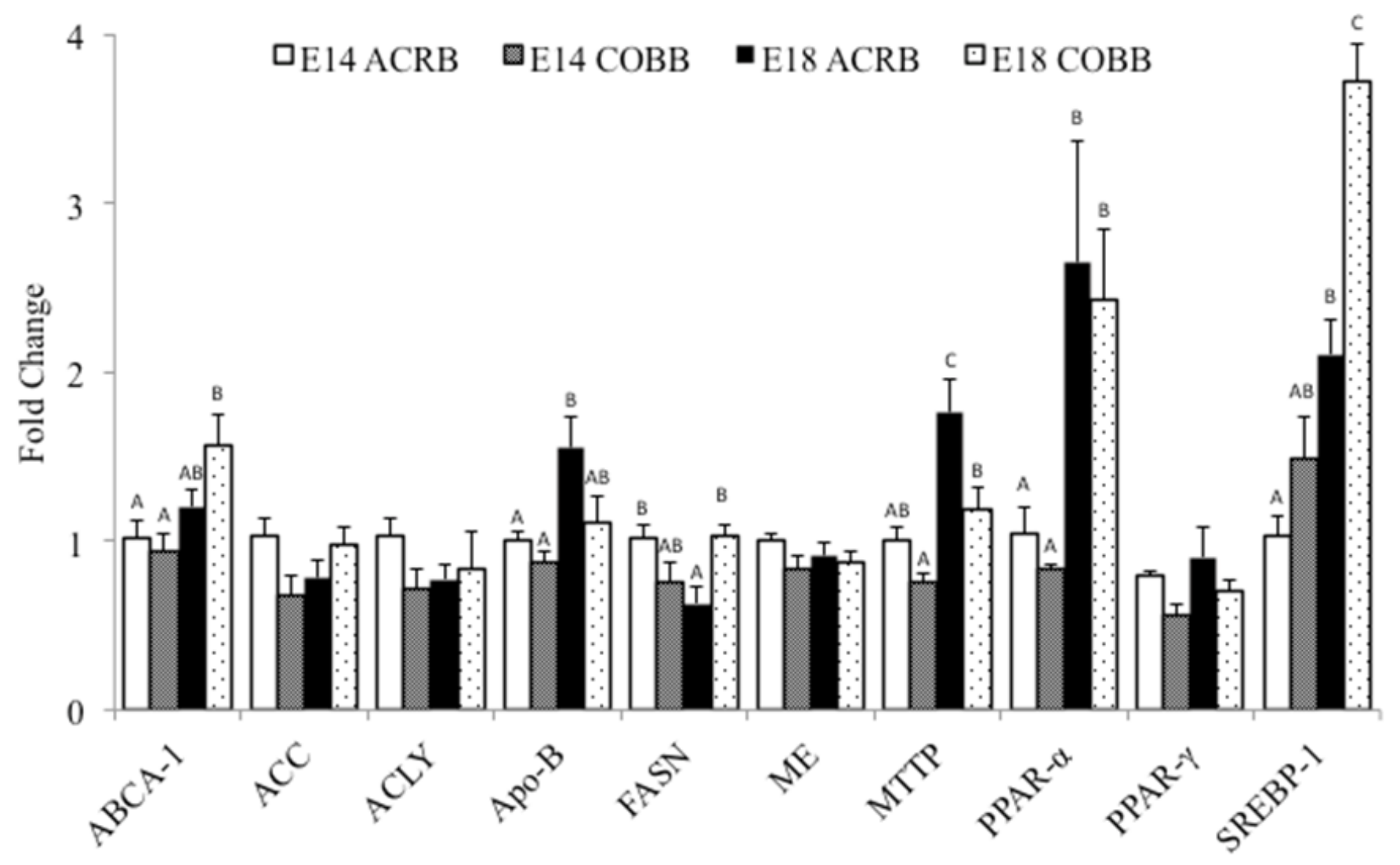

Figure 1

Gene expression in the liver of ACRB and Cobb broilers on E14 and E18. Different letter with in each gene indicated statistic differences in expression level $(p<0.05)$. Abbreviations: ABCA-1 =ATP-binding cassette $1, A C C=$ acetyl coenzyme A carboxylase, $A C L Y=$ adenosine triphosphate citrate lyase, $A p o B=$ apolipoprotein $B, F A S N=$ fatty acid synthase, MTTP =Microsomal triglyceride transfer protein, PPARa = peroxisome proliferator-activated receptor $a$, PPARY =peroxisome proliferator-activated receptor $\gamma$, and SREBP-1 =sterol regulatory element-binding protein 1. 


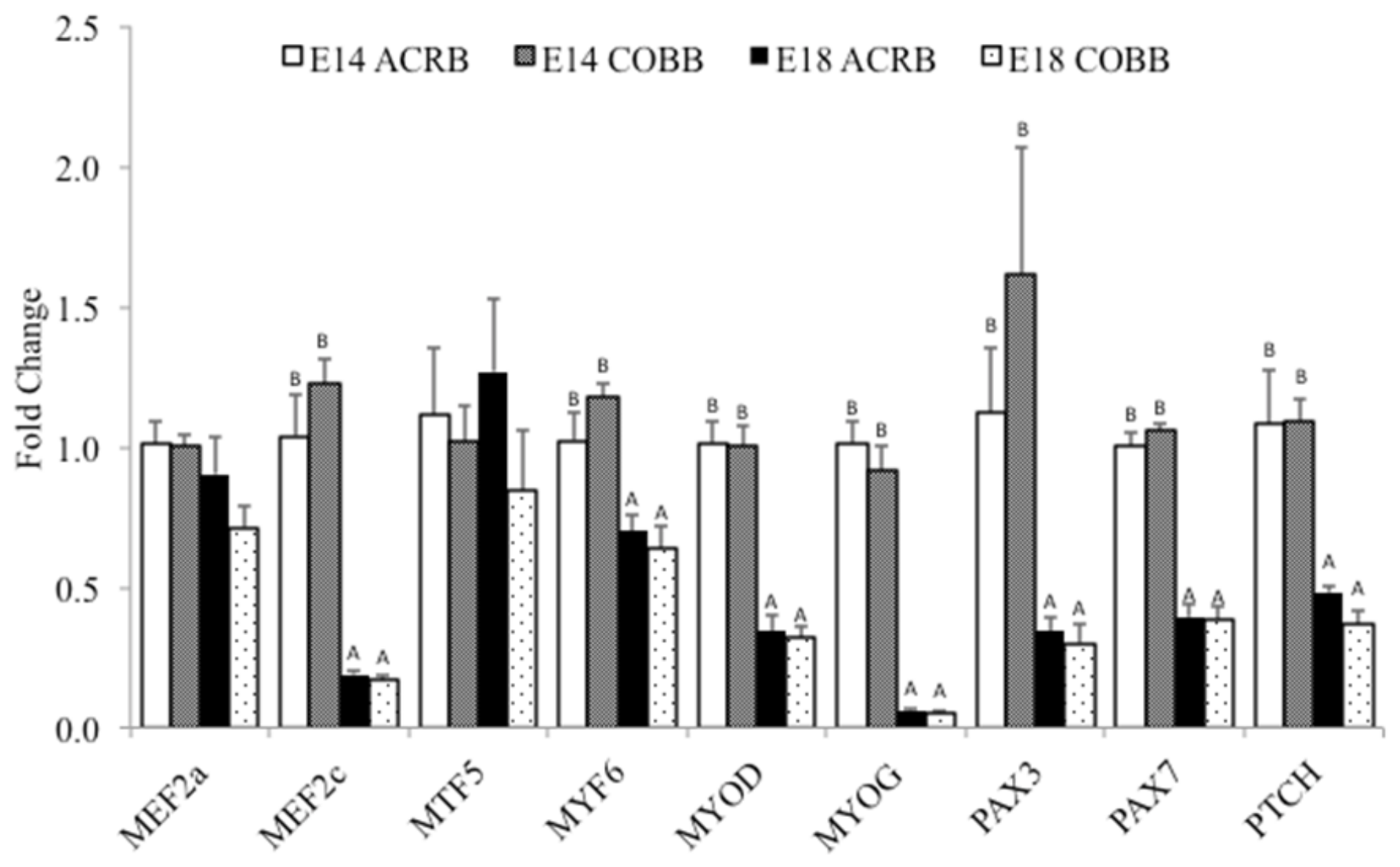

Figure 2

Gene expression in the muscle of ACRB and Cobb broilers on E14 and E18. Different letter with in each gene indicated statistic differences in expression level $(p<0.05)$. Abbreviations: MEF2a=Myocyte Enhancer Factor 2A, MEF2c= Myocyte Enhancer Factor 2C, MYF5 =Myogenic factor 5, MYF6= Myogenic factor 6, MYOD=Myoblast determination protein, MYOG=Myogenin, PAX3=Paired box protein Pax-3, PAX7=Paired box protein Pax-7, PTCH=Protein patched homolog.

A

\section{Figure 3}

Liver development and lipid deposition. The embryonic day and breed information is indicated in the upper right corner in each picture. Arrows indicate lipid deposit in hepatocytes. CV= central vein, $\mathrm{Hp}=$ hepatocytes, * indicates sinusoidal capillaries. Bar is $200 \mu \mathrm{m}$. 
-ACRB
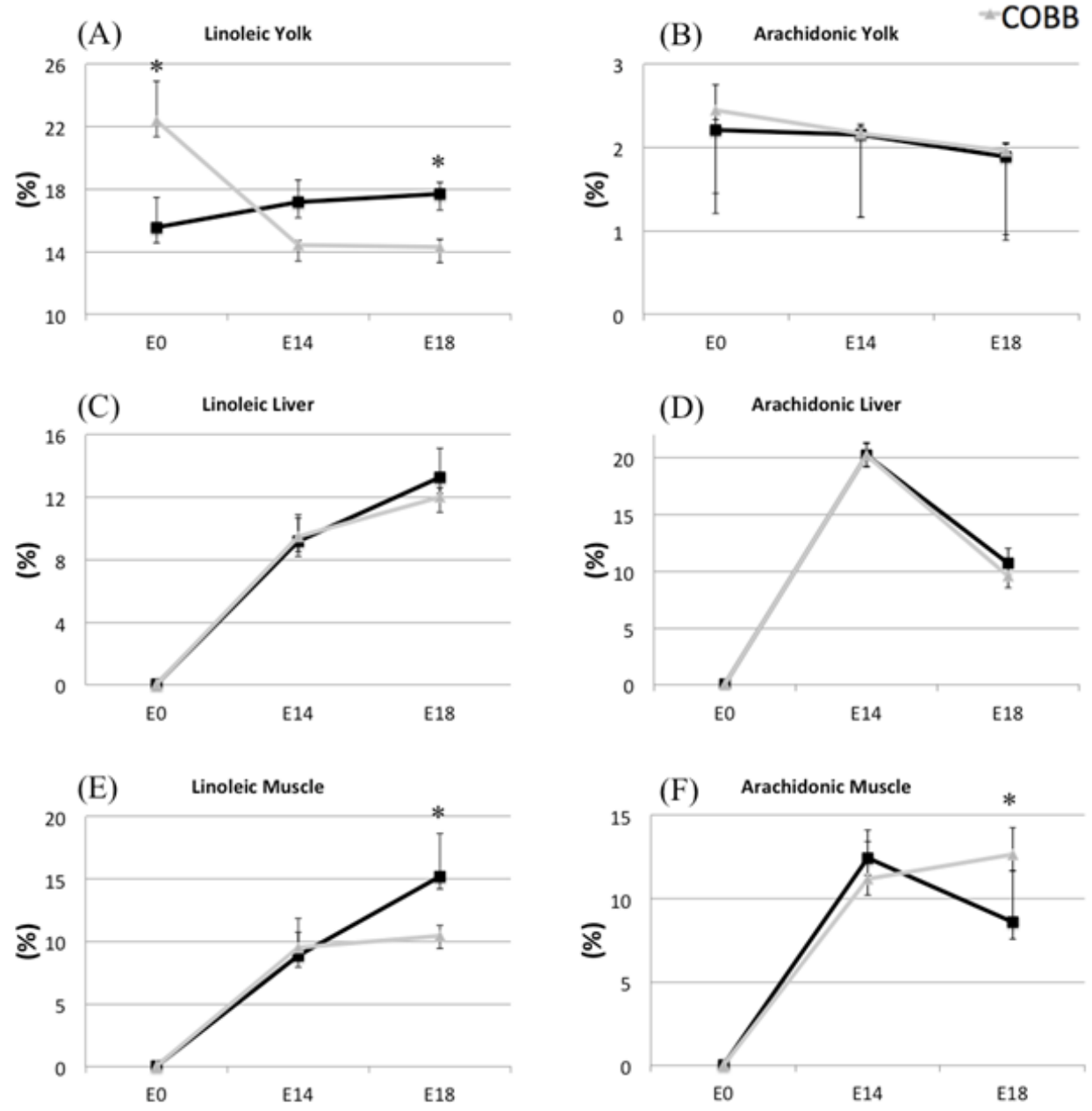

\section{Figure 4}

Dynamic distribution of linoleic and arachidonic acid in chicken embryo. Black squires represent ACRB, gray triangles represent Cobb chicken. Y-axis is the percentage of indicated fatty acid in total fatty acid of designated tissue. * indicates statistical difference of the same age $(p<0.05)$. 